$12-1-2015$

\title{
The Costs of Regulatory Redundancy: Consumer Protection Oversight of Online Travel Agents and the Advantages of Sole FTC Jurisdiction
}

James C. Cooper

Follow this and additional works at: http://scholarship.law.unc.edu/ncjolt

Part of the Law Commons

\section{Recommended Citation}

James C. Cooper, The Costs of Regulatory Redundancy: Consumer Protection Oversight of Online Travel Agents and the Advantages of Sole FTC Jurisdiction, 17 N.C. J.L. \& Tесн. 179 (2015).

Available at: http://scholarship.law.unc.edu/ncjolt/vol17/iss2/1 
North CARolina JOURnAL OF LAW \& TECHNOLOGY

VOLUMe 17, Issue 2: DeCEMBER 2015

\title{
THE COSTS OF REgUlATORY REDUNDANCY: Consumer Protection Oversight OF OnLine Travel Agents AND THE AdVAntages of Sole FTC JuRisdiction
}

\begin{abstract}
James C. Cooper*
Every administration in recent history has attempted to reduce regulatory redundancies. One area of regulatory redundancy that deserves attention is the Federal Trade Commission's (FTC) and Department of Transportation's (DOT) consumer protection authority over online travel agents (OTAs), which generated \$111 billion in revenue in 2013. This regulatory redundancy guarantees that two agencies will oversee OTAs, prevents harmonization of online consumer protection policy, and is likely to impose unnecessary costs on OTAs to adhere to two separate regulatory regimes. The importance of this conflict will grow as privacy and data security become preeminent consumer protection issues and DOT expands its jurisdiction to online information providers. Efficiency suggests the FTC as the sole consumer protection overseer of OTAs. Only the FTC has the current capacity to regulate all OTA activities, and it enjoys unrivaled expertise with respect to e-commerce consumer protection. Further, in contrast with the FTC's ex post enforcement approach, which focuses on actual or likely consumer harm, DOT's ex ante regulatory approach is ill-suited for the fast moving world of e-commerce. Finally, the FTC faces more serious internal and external constraints on its enforcement authority, which tends to temper the potential for regulatory overreach. There are several possible ways to effect this regulatory reform, ranging from the complete abolition of DOT's aviation consumer protection authority and the FTC Act's common carrier exemption, to a memorandum of understanding between FTC and DOT that harmonizes policy.
\end{abstract}

\footnotetext{
${ }^{*}$ George Mason University School of Law, Director of Research \& Policy, Law $\&$ Economics Center, and Lecturer in Law. I thank John Magruder for outstanding research assistance and Expedia for financial support. The views expressed herein are my own.
} 


\section{TABLE OF CONTENTS}

I. INTRODUCTION...............................................................181

II. DOT \& FTC CONSUMER PROTECTION AUTHORITY .........185

A. The DOT's Role ........................................................... 185

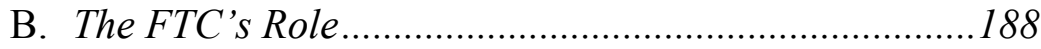

C. Concurrent FTC-DOT Consumer Protection Jurisdiction Over OTAs ..........................................................190

III. The COSTS OF REgulatory REDUNDANCY .....................193

A. Government Inefficiencies Due to Duplication of Effort and Coordination Costs.............................................193

B. Industry Costs From Compliance with Multiple and Inconsistent Regulatory Regimes...............................195

IV. THE CASE FOR THE FTC...............................................196

A. Scope Economies in Enforcement .............................197

B. Institutional Competence ..........................................198

C. Flexibility from Ex-Post, Harm-Based Enforcement ....204

D. External and Internal Constraints .............................211

1. Judicial Review.............................................211

2. Internal Procedures ............................................214

3. Regulatory Capture ...........................................216

V. Possible SOLUTIONS ..........................................................216

VI. ConCluSION ....................................................................219 


\section{INTRODUCTION}

Every administration in recent history has attempted to reform the inevitable overlaps and redundancies that arise from an evergrowing federal bureaucracy. President Reagan established the Office of Information and Regulatory Affairs ("OIRA") to "minimize duplication and conflicts of regulations." Al Gore famously headed President Clinton's "Reinventing Government" initiative, which strove to streamline government functioning and ultimately recommended consolidation or elimination of several agencies. ${ }^{2}$ Most recently, President Obama issued an executive order in an attempt to ameliorate the problem of "redundant, inconsistent, or overlapping" regulatory requirements and assigned his OIRA chief, Cass Sunstein, the task of pruning the regulatory thicket. ${ }^{3}$ There are myriad examples of agencies that have regulatory responsibility over the same area. For example, the Federal Trade Commission ("FTC") and the Department of Justice ("DOJ") share responsibility for enforcing the antitrust laws; the Federal Reserve, Consumer Financial Protection Bureau ("CFPB"), and the Federal Deposit Insurance Company ("FDIC") share regulatory authority over banks; the Food \& Drug Administration ("FDA") and the U.S. Department of Agriculture ("USDA") share regulatory authority over food safety. ${ }^{4}$ Indeed, President Obama quipped in his 2011 State of the Union address announcing his proposal to reduce regulatory inefficiencies, "[ $t]$ he Interior Department is in charge of salmon while they're in fresh water, but the Commerce Department handles them when they're

\footnotetext{
${ }^{1}$ Exec. Order No. 12866, 58 C.F.R. 51,735(2)(b) (1993).

${ }^{2}$ See Al Gore, From Red Tape to Results: Creating A Government ThAT Works BetTer \& COSTS Less, Report of THE NATIONAL PERFORMANCE REVIEW (1993).

${ }^{3}$ Exec. Order No. 1356376, 76 C.F.R. 3821 (2011).

${ }^{4}$ See Jody Freeman \& Jim Rossi, Agency Coordination in Shared Regulatory Space, 125 HARV. L. REV. 1131, 1146-50 (2012) (listing areas of overlapping jurisdiction); Jason Marisam, Duplicative Delegations, 63 ADMIN. L. REV. 181, 187 (2011) (listing areas of overlapping jurisdiction). See also GAO,-11-318SP, OpPortunities tO REDUCE POSSIBLE DUPliCATION IN Government Programs, Save Tax Dollars, And Enhance Revenues (2011) (finding thirty-four areas of regulatory redundancy that could be consolidated).
} 
in saltwater. I hear it gets even more complicated once they're smoked." 5

One area of regulatory redundancy that deserves attention is the FTC's and Department of Transportation's ("DOT") consumer protection authority over online travel agents ("OTAs"), such as Travelocity, Expedia, and Orbitz. The FTC enforces Section 5 of the FTC Act, which broadly prohibits "unfair and deceptive acts or practices." "With the exception of some carve-outs, Section 5 gives the FTC jurisdiction over almost all of the Internet economy. ${ }^{7}$ Although the FTC is barred by statute from regulating airlines directly, it has asserted jurisdiction over OTAs. DOT also has consumer protection authority under Section 411 of the Airline Deregulation Act ("ADA"), which was modeled after the FTC Act but limits its jurisdiction to air carriers and the sale of air transportation by "ticket agents." Because OTAs are considered ticket agents, FTC and DOT have concurrent jurisdiction over OTAs' sales of airline tickets. Although the FTC essentially has abdicated responsibility over OTAs' airline ticket sales to DOT, two forces threaten to bring this dormant conflict to life. First, as privacy and data security have become the preeminent consumer protection concern, ${ }^{9}$ it seems unlikely that the FTC - the national privacy and data security cop - would be so quick to abdicate its jurisdiction over OTAs in the event of a data breach or some other privacy concern that may arise in connection with OTAs' massive collection of consumer data. Second, DOT recently has attempted to expand its definition of "ticket agents" to cover entities that only

\footnotetext{
${ }^{5}$ President Barack Obama, State of the Union Address (Jan. 5, 2011).

${ }^{6} 15$ U.S.C. $\S 45$ (2006).

${ }^{7}$ The Procrustean Problem With Prescriptive Regulation, Remarks of Maureen K. Ohlhausen, Comm'r, U.S. Federal Trade Comm'n (2014), http://www.ftc.gov/system/files/documents/public_statements/291361/140318fsf .pdf.

${ }^{8} 49$ U.S.C. $\S 41712$ (2010).

${ }^{9}$ See Julie Brill, Comm'r, Fed. Trade Comm'n, Keynote Address Before the USCIB/BIAC/OECD Conference, One Year Later: Privacy and Data Security in a World of Big and Data, THE INTERNET OF THINGS, AND GLOBAL DATA Flows, 1 (March 10, 2015), https:/www.ftc.gov/system/files/documents/ public_statements/629691/150310uscibremarks.pdf.
} 
provide information about airline fares, such as Google or Trip Advisor. ${ }^{10}$ Online advertising, however, is squarely in the FTC's bailiwick.

This regulatory redundancy is bad government. It guarantees that two agencies will oversee OTAs-DOT for air travel sales, and FTC for hotels and rental cars - when one agency could do the job more efficiently. Further, it prevents harmonization of online consumer protection policy. The FTC has been the leader in addressing consumer protection in e-commerce. Not only is such regulatory redundancy wasteful for taxpayers, it threatens to impose serious costs on one of the largest Internet businesses and ultimately the consumers. The online travel industry is a key driver of e-commerce growth, earning $\$ 111$ billion in 2013, which amounts to one-third of all e-commerce revenue. ${ }^{11}$ Almost half of travel is booked online, with OTAs responsible for about a quarter of this revenue. ${ }^{12}$ Having one set of rules for online sales of airline tickets and another for the rest of the Internet also is likely to impose unnecessary costs on this important sector associated with adherence to two separate regulatory regimes.

Avoiding this potential regulatory conflict suggests a fix that selects one agency to provide consumer protection oversight of OTAs. The FTC is the clear choice. First, and perhaps most obviously, only the FTC has the current capacity to regulate all OTA activities, rather than merely the portion that deals with airlines. Second, as the primary federal consumer protection enforcer for over seventy years, the FTC enjoys unrivaled expertise, especially with respect to e-commerce. ${ }^{13}$ Further,

\footnotetext{
${ }^{10}$ See infra Part II.A.

${ }^{11}$ According to Phocuswright, consumers purchased $\$ 132$ billion worth of travel online in 2013, compared with $\$ 262$ billion for the remainder of ecommerce revenue in 2013. See Phocuswright, U.S. Online Travel Overview, Figure 1.11 (2014).

${ }^{12}$ See Phocuswright, U.S. Online Travel Overview, Figures 1.11, 1.19 (2013) ( $43 \%$ of travel is booked online).

${ }^{13}$ In 1938, the Wheeler-Lea Amendments to the FTC Act gave the FTC its consumer protection power over "unfair and deceptive acts and practices." See
} 
complementing its experience in the field, the FTC additionally enjoys a research capability-approximately eighty Ph.D. economists and a long and distinguished history of producing firstrate public policy research ${ }^{14}$ - that DOT lacks, and which has served it well in identifying potential harms and crafting policy. Third, DOT's heavy-handed ex ante regulatory approach is illsuited for the fast moving world of e-commerce; FTC's ex post enforcement approach, which focuses on actual or likely consumer harm, is far more nimble and likely to allow innovation to flourish. Finally, the FTC faces more serious internal and external constraints on its enforcement authority, which tends to produce consensus-based action and tempers the potential for regulatory overreach.

There are several possible ways to effect this regulatory reform, ranging from the complete abolition of DOT's aviation consumer protection authority and the FTC Act's common carrier exemption, to a memorandum of understanding between FTC and DOT, under which DOT will agree to defer to FTC's consumer protection authority over OTAs.

This paper proceeds as follows. Part II provides background on both FTC and DOT consumer protection authority. Part III explains the costs of redundant regulatory oversight in this area, including its impact on "good government" and industry efficiency. Part IV makes the case for vesting the FTC with sole consumer protection authority over OTAs, and Part V sketches out possible means for effecting this reform. The final Part concludes the paper.

Section Wheeler-Lea Amendments of 1938, § 1, Pub. L. No. 75-447, 52. Stat. 111, 111 (1938).

${ }^{14}$ See FTC Bureau of Economics, https://www.ftc.gov/about-ftc/bureausoffices/bureau-economics; Joshua D. Wright, How to Regulate the Internet of Things Without Harming its Future: Some Do's and Don'ts, FED. TRADE COMM'N, 16-18 (May 21, 2015), https://www.ftc.gov/system/files/documents/ public_statements/644381/150521iotchamber.pdf. 


\section{DOT \& FTC Consumer Protection Authority}

DOT and FTC consumer protection authorities have very different origins. The DOT is an industry-specific regulator, whose consumer protection jurisdiction over airlines and, by extension, ticket agents, is an artifact of airline deregulation. The FTC, on the other hand, was created over a century ago with a broad mandate to be the nation's consumer protection authority. Further, these agencies exercise their mandates in completely different manners. The DOT, especially in recent years, has chosen to promulgate rules that lay out required conduct for airlines and ticket agents. On the other hand, since the 1980s, the FTC has exercised its consumer protection authority through enforcement against practices that give rise to consumer harm.

\section{A. The DOT's Role}

In 1978, the ADA freed commercial aviation from government control of rates and routes. ${ }^{15}$ Prior to the ADA, the Civil Aeronautics Board ("CAB") regulated all aspects of commercial air transportation, including rates and entry. ${ }^{16}$ After the $\mathrm{CAB}$ was dissolved in 1985, Congress transferred its consumer protection authority over air travel to DOT. ${ }^{17}$ Specifically, the ADA provided DOT the authority to "investigate and decide whether an air carrier, foreign air carrier or ticket agent has been or is engaged in an unfair or deceptive practice or an unfair method of competition in air transportation or the sale of air transportation." ${ }^{18}$ Importantly, Congress modeled this provision after Section 5 of the FTC Act, and DOT has looked to FTC Act precedent to decide whether an

\footnotetext{
${ }^{15}$ Airline Deregulation Act of 1978, Pub. L. No. 95-504, 95959592 Stat. 1705 (1978).

${ }^{16}$ This regulation was designed largely to guarantee "reasonable" level of profitability for airlines. See VISCUSI, HARRINGTON, AND VERnON, THE ECONOMICS OF REGULATION AND ANTITRUST 612-13 (4th ed. 2005) [hereinafter Viscusi et al.].

${ }^{17}$ This decision was in large part due to the FTC's lack of common carrier jurisdiction. See H.R. 2862, 114th Cong. (2015).

1849 U.S.C. $\S 41712$. The Aviation Consumer Protection Bureau carries out these consumer protection provisions.
} 
act is unfair or deceptive. ${ }^{19}$ The ADA further defines a ticket agent as, "a person ... that as a principal or agent sells, offers for sale, negotiates for, or holds itself out as selling, providing, or arranging for, air transportation." ${ }^{20}$ The DOT mandate allows it to adopt regulations and to proceed with enforcement against entities within its jurisdiction that are engaged in unfair or deceptive acts. ${ }^{21}$ It can obtain both injunctive relief and civil penalties for violating rules. ${ }^{22}$

In recent years, DOT has exercised its consumer protection authority through rulemaking, which mandates and proscribes certain conduct for airlines and ticket agents. ${ }^{23}$ In 2009, DOT finished a two-year rulemaking process by promulgating its Enhancing Airline Passenger Protections ("EAPP-I") rule. ${ }^{24}$ Among other things, this rule requires air carriers to adopt and publish tarmac delay contingency plans and customer service plans, publish flight delay information, and it deems "continued delays on a flight that is chronically late" to be an unfair and deceptive practice. ${ }^{25}$ DOT quickly followed with EAPP-II, which requires airlines and ticket agents (including OTAs) to display the

${ }^{19}$ See Cong. Rep. at 2860 (Section 411 "Duplicates the Authority which the Federal Trade Commission has to protect consumers in other industries under Section 5 of the FTC Act.").

${ }^{20} 49$ U.S.C. $\S 40102(a)(45)(2012)$.

${ }^{21} 49$ U.S.C. $\$ 41712(2010)$.

${ }^{22}$ See 49 U.S.C. $§ 41712$ (a) (2010) (injunctive relief); 49 U.S.C. $§ 46301$ (2014) (civil penalties).

${ }^{23}$ Since the beginning of 2012, only two out of fifty-one DOT aviation consumer protection cases were not based on regulatory rule violations. DEP'T OF TRANSP., Consent Order, Lufthansa German Airlines, No. 2015-0002 (Jan. 22, 2015); (DEP'T of TrANSP., Consent Order, Aviation Services, Ltd., No. 2012-0002 (Jan 27, 2012). Forty-five of these cases included violations of the Full Fare Advertising Rule; see also Joanne W. Young \& Lyndsey M. Grunewald, Supreme Court Review of DOT Actions: An Opportunity to Discipline Government Efforts to Re-Regulate the Industry, 25 AIR \& SPACE LAWYER 11, 15 (2013) (more recent DOT consumer protection rulemaking has not followed the "restrained approach" that considers "compelling evidence of consumer deception").

${ }^{24}$ Enhancing Airline Passenger Protections, 74 Fed. Reg. 68,983 (Dec. 20, 2009).

${ }^{25} I d$. 
fare inclusive of all government fees and taxes. ${ }^{26}$ The rule also requires air carriers to allow consumers to cancel their tickets (purchased at least two-weeks prior to travel) within 24 hours without penalty. ${ }^{27}$ DOT justified both rules as an effort to remedy unfair or deceptive practices, and the D.C. Circuit recently upheld them as a reasonable exercise of DOT's authority. ${ }^{28}$

Last year, DOT proposed a new set of regulations that would go further than the EAPP rules. ${ }^{29}$ Notably, the proposed rule would expand customer service obligations to ticket agents, ${ }^{30}$ require large ticket agents to maintain a public list of the carriers whose tickets they sell, and prohibit "display biases" by mandating the order in which customer-facing search flight search products display results. ${ }^{31}$ Importantly, this proposal also would "clarify" DOT's increasingly broad definition of "ticket agents" to include websites that provide search tools for flight information, but do not themselves sell air transportation. ${ }^{32}$ As a practical matter, this rule

\footnotetext{
${ }^{26}$ Enhancing Airline Passenger Protections, 76 Fed. Reg. 23,110 (Apr. 25, 2011). This full-fare advertising rule is a reversal of its policy in place since 1984, which allowed prices to exclude per capita taxes and fees as long as they were displayed prominently. See Edward W. Sauer \& Carlos P. Martins, Regulation of Airfare Advertising in the United States and Canada, 25 AIR \& SPACE LAWYER 17, 18 (2012).

${ }^{27} I d$.

${ }^{28}$ See Spirit Airlines, Inc. v. Dep't of Transp., 687 F.3d 403 (D.C. Cir. 2012). Spirit Airlines also lost a challenge to the EAPP under the First Amendment.

${ }^{29}$ Transparency of Airline Ancillary Fees and Other Consumer Protection Issues, 79 Fed. Reg. 29,970 (NPRM May 23, 2014).

${ }^{30}$ Specifically, it would require large ticket agents to provide prompt refunds when they are due; provide an option to hold a reservation at the quoted price without payment for 24 hours; disclose cancellation policies, and lavatory and seating configurations; notify customers of itinerary changes in a timely manner; and respond promptly to customer complaints. Conservation Stewardship Program Interim Rule, 79 Fed. Reg. at 29,982-86.

${ }^{31}$ Transparency of Airline Ancillary Fees and Other Consumer Protection Issues, 79 Fed. Reg. 29,970, 29,971.

${ }^{32}$ Sites like Google and Kayak merely provide links to sites that actually sell transportation. The proposal is designed "to make clear that all entities involved in the sale or distribution of air transportation, including those intermediaries that do not themselves sell air transportation and receive compensation in connection with the sale of air transportation, are ticket agents subject to
} 
would bring online sites like Google, Trip Advisor, and Kayak under DOT's consumer protection jurisdiction as "ticket agents." 33 This would mean that they would be subject to DOT's fare display requirements, and would be required to show baggage fees and code share operations. Further, these search entities would be subject to DOT's proposed prohibition on "display bias."

\section{B. The FTC's Role}

Congress gave the FTC authority to take action against "unfair or deceptive acts or practices in or affecting commerce." 34 Although the FTC once engaged in a host of industry rulemakings under its consumer protection authority, regulatory overreaches of the 1960s and 1970s - and the concomitant political backlashled the FTC to adopt a harm-based approach that instead relies on adjudication. ${ }^{35}$

Buoyed by the Supreme Court's approval of an expansive authority under Section 5, the D.C. Circuit's approval of the FTC's ability to promulgate trade regulations rules under its consumer protection authority, ${ }^{36}$ and empowered by the 1975 MagnusonMoss Federal Trade Commission Improvement Act, ${ }^{37}$ the FTC embarked on a flurry of rulemakings in the 1970s that nearly led to

[DOT's] regulations regarding the display of airfare information." Transparency of Airline Ancillary Fees and Other Consumer Protection Issues, 79 Fed. Reg. 29,970, 29,973.

${ }^{3}$ See, e.g., Comments of Google, Inc. et al., Transparency of Airline Ancillary Fees and Other Consumer Protection Issues, No. DOT-OST-20140056 (Sept. 19, 2014).

${ }^{34}$ Congress added the prohibition on "unfair or deceptive acts or practices" as part of the Wheeler-Lea Amendments in 1938. Wheeler-Lea Amendments of 1938, § 1, Pub. L. No. 75-447, 52. Stat. 111, 111 (1938). This provision has been interpreted to form the basis of the Commission's consumer protection authority. See Fed. Trade Comm'n. Policy Statement of Unfairness, appended to In re International Harvester Co., 104 F.T.C. 949 (1984), available at http://www.ftc.gov/bcp/policystmt/ad-unfair.htm.

${ }^{35}$ See William MacLeod et al., Three Rules and a Constitution, 72 ANTITRUST L.J. 943 (2005).

${ }^{36}$ See FTC v. Sperry-Hutchinson Co., 405 U.S. 233 (1972); National Petroleum Refiners v. FTC, 482 F.2d 672 (D.C. Cir. 1973).

${ }^{37} 15$ U.S.C. $\S \S 2301-12$. 
its demise. The proverbial straw that broke the camel's back was the proposed children's advertising rule, which would have barred not only all advertising to young children and the advertising of sugary foods to older children, but also required public service announcements to promote health. ${ }^{38}$ This ill-fated effort earned the FTC the moniker "the national nanny" ${ }^{39}$ and resulted in congressional action limiting the Commission's ability to use its unfairness authority to promulgate advertising regulations. ${ }^{40}$

In an effort to assuage congressional concerns, the FTC issued a series of binding policy statements that would make consumer harm the touchstone of its consumer protection agenda. First, the unfairness statements set up a cost-benefit framework, in which the Commission would challenge a practice as unfair only if: (1) it created substantial consumer injury; (2) that was not outweighed by any benefits to consumers or to competition; and (3) it was not reasonably avoidable by consumers. ${ }^{41}$ The FTC's deception statement requires that a statement be "false or misleading" and "material," in the sense that it impacted the consumer's purchasing decision. ${ }^{42}$ In this manner, the concept of materiality acts as an

${ }^{38}$ See MacLeod et al., supra note 35, at 942, for a full discussion of this episode. For a discussion of the FTC's activism against advertising, see also John E. Calfee, Fear of Persuasion: A New Perspective on Advertising AND REGULATION 11-15 (1997).

${ }^{39}$ The FTC as National Nanny, WASH. Post, Mar. 1, 1978, at A22.

${ }^{40}$ See William E. Kovacic, The FTC and Congressional Oversight of Antitrust Enforcement, 17 TULSA L.J. 587, 665-66 (1982) (detailing these restrictions and noting that the rancor over the FTC caused its funding to lapse twice, causing the Agency to shut its doors).

${ }^{41}$ The Commission first issued the Unfairness Policy Statement in 1980, and later made it binding precedent by appending to the International Harvester decision. See Fed. Trade. Comm'n, Policy Statement on Unfairness, appended to In re International Harvester Co., 104 F.T.C. 949 (1984), available at http://www.ftc.gov/bcp/policystmt/ad-unfair.htm. Congress eventually codified the Unfairness Policy Statement with the 1994 FTC Reauthorization Act.

${ }^{42}$ See FTC Policy Statement on Deception, appended to Cliffdale Assoc., Inc., 103 F.T.C. 110, 175-83 (1984), http://www.ftc.gov/bcp/policystmt/addecept.htm. The Commission also issued a statement on advertising substantiation in Thompson Medical. FTC Policy Statement Regarding Advertising Substantiation, appended to Thompson Medical Co., 104 F.T.C. 
indirect harm requirement - when a false statement is material, it can be assumed to cause harm because it triggered a consumer purchase that otherwise would not have happened. If the unfairness test lays out a quasi-negligence standard (liable only when costs are greater than the benefits), the deception test is one of strict liability for false claims, under the assumption that false claims are never beneficial. ${ }^{43}$

This harm-based approach has led the FTC from an agency on the brink of extinction to a world-class consumer protection agency. ${ }^{44}$ Since the turn of the century, it has used its unfairness and deception enforcement authorities to craft consumer protection policies for the Internet economy, including in the areas of online and mobile disclosures, privacy, and data security. ${ }^{45}$

\section{Concurrent FTC-DOT Consumer Protection Jurisdiction Over OTAS}

As noted above, the DOT has jurisdiction over "ticket agents," which are defined to include an entity that "... holds itself out as

648, 839 (1984), https://www.ftc.gov/public-statements/1983/03/ftc-policystatement-regarding-advertising-substantiation.

${ }^{43}$ See J. Howard Beales III, former Director of Bureau of Consumer Protection, The FTC's Use of Unfairness Authority: Its Rise, Fall, and Resurrection, Remarks at The Marketing \& Public Policy Conference (May 30, 2003) [hereinafter Beales] ("deception analysis essentially creates a shortcut, assuming that, when a material falsehood exists, the practice would not pass the full benefit/cost analysis of unfairness, because there are rarely, if ever, countervailing benefits to deception"), https:/www.ftc.gov/publicstatements/2003/05/ftcs-use-unfairness-authority-its-rise-fall-and-resurrection.

This is analogous to the distinction between rule of reason and per se rules of liability in antitrust. A rule of reason inquiry requires an explicit showing of actual or likely harm, whereas harm is assumed to be greater than benefits from the categories of per se illegal conduct, such as naked agreements to fix prices or allocate markets. See Thomas G. Krattenmaker, Per se Violations in Antitrust Law: Confusing Offenses with Defenses, 77 GEO. L J. 165, 179-80 (1988).

${ }^{44}$ See James C. Cooper, Forward, in James Campbell Cooper ed., THE Regulatory Revolution AT the FTC: A ThiRTy-YeAR PERSPECTIVE ON COMPETITION AND CONSUMER PROTECTION at $x$ (Oxford University Press 2013)

${ }^{45}$ See infra notes 73-79 and accompanying text. 
selling, providing, or arranging for, air transportation.." ${ }^{" 46}$ Although Congress clearly did not anticipate OTAs when it originally brought ticket agents under the then-CAB's authority, the courts have given the definition a broad reading. In Sabre, Inc. $v$. Department of Transportation for example, Sabre argued that DOT's interpretation of "ticket agent" that included computer reservation systems ("CRSs") that were unaffiliated with airlines was an impermissible reading of the statute. ${ }^{47}$ The D.C. Circuit disagreed, holding that the change in the CRS industry was immaterial to whether Congress meant to allow DOT jurisdiction over modern CRSs:

Congress did not define "ticket agents" as persons who are travel agents, nor make the ability to issue a ticket the test of being a ticket agent, but rather defined the words in terms of specific activities, i.e., persons selling air transportation, offering it for sale, or holding themselves out as selling or arranging for air transportation. That CRSs and travel agents conduct related but somewhat different functions in the distribution chain is ... irrelevant. $^{48}$

To avoid duplicative and potentially contradictory regulation, Congress exempted from FTC jurisdiction "common carriers subject to the Acts to regulate commerce," which the FTC Act defines as entities "subject to regulation as interstate transportation providers or subject to the Communications Act of 1934." ${ }^{49}$ Accordingly, the FTC clearly lacks jurisdiction over airlines' ticket sales and has admitted as much. ${ }^{50}$ However, because OTAs are not

\footnotetext{
${ }^{46} 49$ U.S.C. $\S 40102(a)(45)$ (2012).

${ }^{47}$ Sabre, Inc. v. Dep't of Transp., 429 F.3d 1113, 1115 (D.C. Cir. 2005).

${ }^{48} I d$. at 1125 .

${ }^{49} 15$ U.S.C. $\$ 44$ (2006).

${ }^{50}$ For example, when proposing a revision to its "Guides for the Use of Environmental Marketing Claims," the FTC initially used an airline advertisement as an example of a potentially deceptive claim about carbon offsets, see Air Transport Association, Comment Letter on the Federal Trade Commission's Proposed Revisions to the Guides for the Use of Environmental Marketing Claims (Dec. 10, 2010), https:/www.ftc.gov/sites/default/files/ documents/public_comments/guides-use-environmental-marketing-claimsproject-no.p954501-00314\%C2\%A0/00314-57127.pdf. The statement
} 
common carriers, but merely sell tickets for common carriers, the FTC takes the position that they are not covered by the FTC Act's common carrier exemption. ${ }^{51}$

Thus, it would seem that the FTC and DOT share concurrent consumer protection jurisdiction over OTAs' sales of airline tickets. To this point, conflict has been avoided because the FTC seemingly has ceded its jurisdiction over the airfare piece of OTAs to DOT. ${ }^{52}$ Two developments suggest that regulatory conflict-and all of its attendant costs, which are discussed below-may be looming just beyond the horizon. First, privacy and data security issues in e-commerce are becoming the preeminent part of the FTC's consumer protection portfolio. ${ }^{53}$ As an artifact of the nature of their business and the substantial role that they play in ecommerce, OTAs collect volumes of sensitive consumer data. Further, it is likely to be harder to compartmentalize data practices than to design different displays for various product line offerings. Thus, to the extent that the FTC was to extend its consumer protection authority to data practices of OTAs based on hotels and cars, whatever it prescribed would almost necessarily bleed into the airline sales side, necessitating DOT and FTC coordination. ${ }^{54}$

accompanying the final version of the guidelines replaced the example of an airline advertisement with an OTA advertisement, noting "the airline industry is exempt from Section 5 of the FTC Act .... The Commission, however, has jurisdiction over non-carrier third parties ...." Fed. TRADE COMM'N, ThE GREEN GUIDES: STATEMENT OF BASIS AND PURPOSE 21 (2012).

${ }^{51}$ Fed. TRADE COMM'N, supra note 50, at 21. That Congress assigned jurisdiction over only airlines, and not ticket agents, in COPPA also suggests that FTC and DOJ enjoy concurrent jurisdiction over ticket agents. See 15 U.S.C. § 6505(c).

${ }^{52}$ Fed. TRADE COMM'N, supra note 50, at 21.

${ }^{53}$ See supra note 9 , at 1.

${ }^{54}$ Indeed, FTC and DOT met to discuss privacy issues because of their potentially overlapping authority. See FoURTH MEETING OF ADVISORY Committee on AViation Consumer Protection, Minutes, (May 21, 2013) $\mathrm{http} / / / \mathrm{www}$.airlineinfo.com/ostpdf88/135.pdf. At that meeting, a representative from the FTC noted that the changing industry landscape is leading to "an overlap between and DOT and FTC jurisdiction." Id. at 10 . 
The second circumstance that threatens to bring FTC and DOT into conflict is DOT's position that websites that provide flight search tools and derive advertising revenue from this display, but which do not themselves sell tickets, qualify as "ticket agents" for the purpose of its consumer protection regulation. ${ }^{55}$ As explained above, this new proposal would bring online sites like Google, Kayak, and Trip Advisor, under its consumer protection jurisdiction. ${ }^{56}$ As DOT expands its consumer protection jurisdiction from its core area of expertise into online advertising sites, it will encroach into a regulatory space that the FTC has owned since ecommerce began.

\section{The COSTS OF REgULATORY REDUNDANCY}

Regulatory duplication is widespread and almost never by design, but rather "unintended or incidental to other aims, typically emerging as the byproduct of the policy ad hoc process through which agencies are designed." ${ }^{57}$ That is the case here. When Congress vested consumer protection oversight over airlines to DOT, it did so understanding that the FTC lacked jurisdiction over common carriers. ${ }^{58}$ Congress could not have imagined OTAs, or that by including "ticket agents" in DOT's jurisdiction, would create a regulatory redundancy that impacted a large share of Internet commerce. Such redundancies give rise to two broad inefficiencies. First, it is wasteful to have two agencies performing essentially the same task. Second, it is costly for regulated entities to adapt to two potentially conflicting standards.

\section{A. Government Inefficiencies Due to Duplication of Effort and Coordination Costs}

It is wasteful for taxpayers to foot the bill for two agencies to perform what is essentially the same function, but this is the status

\footnotetext{
${ }^{55}$ See, e.g., Hipmunk, Inc., DOT Order 2013-8-8, Docket No. OST-20130004 (Aug. 20, 2013); see also In re Trip Advisor (2012).

5679 Fed. Reg. at 29,973 (May 23, 2014).

${ }^{57}$ Jason Marisam, Duplicative Delegations, 63 ADMIN. L. REV. 181, 184 (2011).

${ }^{58}$ See 15 U.S.C. $\S 44$ (2006).
} 
quo with respect to OTAs. Currently, although the FTC has claimed jurisdiction over the full gamut of OTA offerings, it has essentially abdicated its jurisdiction with respect to airfare offerings. ${ }^{59}$ Given DOT's limited jurisdiction (limited only to the sale of air transportation), the current state of affairs guarantees that two agencies will perform oversight of OTAs when it could be done as effectively with one. ${ }^{60}$

Potentially overlapping jurisdiction also leads to coordination costs, which can be substantial. ${ }^{61}$ When one agency wants to take a regulatory action, it must devote staff time to consult with its sister agency. FTC and DOJ, for example, must coordinate in merger reviews and antitrust investigations, as both enforce the Sherman Act. ${ }^{62}$ These consultations can lead to ugly turf battles, which delay investigations. ${ }^{63}$ Until recently, there appeared to be little in the way of coordination between FTC and DOT with respect to consumer protection authority over OTAs. As privacy and data security have mushroomed into the top consumer protection issues, DOT and FTC reportedly have begun to discuss their regulatory approaches. ${ }^{64}$ Given the role that OTAs play in e-commerce, it will be important for FTC and DOT to harmonize their approaches to how OTAs collect, use, and store consumer data. Such harmonization, however, is not free. It is true that when agencies must coexist in regulatory space, coordination is preferable to the

\footnotetext{
${ }^{59}$ This may be a rational response to unclear jurisdictional boundaries. See id. (noting that abdication is the primary vehicle through which agencies avoid conflict).

${ }^{60}$ See supra Part II.A.

${ }^{61}$ See Jody Freeman \& Jim Rossi, Agency Coordination in Shared Regulatory Space, 125 HARV. L. REV. 1131, 1182 (2012), [hereinafter Freeman and Rossi].

${ }^{6}$ See Memorandum of Agreement Between the Federal Trade COMMISSION AND THE ANTITRUST Division OF THE UNITED STATES DePARTMENT OF Justice CONCERning Clearance Procedures For INVESTIGATION at 5, (Mar. 5, 2002), http://www.justice.gov/atr/memorandumagreement-between-federal-trade-commission-and-antiturst-division-unitedstates.

${ }^{63}$ Freeman and Rossi, supra note 61, at 1146, 1165-66.

${ }^{64}$ See supra note 9 , at 1.
} 
alternative-inconsistent policies. ${ }^{65}$ However, the ideal solution is to avoid these costs altogether, which can be accomplished through consolidation of functions.

\section{B. Industry Costs From Compliance with Multiple and Inconsistent Regulatory Regimes}

Not only is overlapping jurisdiction inefficient government, it forces industry to comply with multiple, and potentially inconsistent regulatory regimes. This is especially the case for OTAs given DOT's incomplete jurisdiction; DOT can regulate only the airfare piece of an OTA's offering. Thus, OTAs must comply with Section 5's requirement for hotel and car rental offerings, and DOT regulation for airfare offerings. Discrepancies between FTC and DOT policies are especially troubling because they enforce identical statutory language. As noted in Part II, Congress designed DOT's consumer protection authority to be a carbon copy of the FTC's. Having "unfair and deceptive" mean one thing to DOT and another to FTC is the model of poor governance and surely increases business uncertainty.

Such a scenario is not merely an academic hypothetical. Take for example the "full fare" provisions from EAPP-II and DOT's most recent proposed consumer protection regulation to require OTAs to disclose affiliations and financial arrangements that they may have with certain airlines, and order their search results in a "non-biased" manner. ${ }^{66}$ The FTC does not mandate such displays or disclosures, nor require any ordering for searches. ${ }^{67}$ Accordingly, OTAs must develop one type of display and search algorithm for airfares and another for hotels and cars. These requirements may be especially burdensome as mobile interfaces play an increasingly important role in OTA sales. ${ }^{68}$

\footnotetext{
${ }^{65}$ See Freeman and Rossi, supra note 61, at 1173-81 (noting executive branch tools for managing duplication).

6679 Fed. Reg. 29970 (May 23, 2014).

${ }^{67}$ See infra note 90.

${ }^{68}$ See Marcello Gasdia, Mobile Travel Shopping Hits Tipping Point - But PC Still Dominates Booking (Jan. 2015), http://www.phocuswright.com/Travel-
} 
Another area that highlights further potential inefficiencies is privacy and data security. As noted above, FTC, DOT, and industry representatives recently met to discuss privacy and data security as it relates to online booking of air travel. ${ }^{69}$ Importantly, the DOT representative explained that it would find a privacy or data security practice unfair under Section 41712 in broader circumstances than the FTC would find a violation of Section 5. ${ }^{70}$ More specifically, he explained that it would target an airline or an OTA for committing an "unfair" act or practice if its data practices "violated a public policy" or engaged in "immoral" behavior. ${ }^{71}$ These factors represent a more stringent application of unfairness than Section 5: the FTC jettisoned morality as an unfairness factor in the 1980s, and can consider public policy only as an additional factor-it alone cannot serve as the basis for a Section 5 violation. ${ }^{72}$ Thus, OTAs must contend with two potentially different privacy and security standards: one for data collected from consumers related to hotel rooms and car rentals, and another for data collected for airfares. ${ }^{73}$

\section{THE CASE FOR THE FTC}

Not only does efficiency call for eliminating costly duplicative regulation of OTAs, but it also calls for vesting authority with the agency best equipped to handle the task. The evidence suggests that authority should fall to the FTC. First, as explained above, only the FTC has current authority to oversee the entire OTA portfolio of offerings, which allows it to enjoy scope economies in

Research/Research-Updates/2015/Mobile-Travel-Shopping-Hits-Tipping-PointBut-PC-Still-Dominates-Booking\#.VhGKI0uKnx8.

${ }^{69}$ See supra note 54.

${ }^{70}$ See supra note 54 , at 9-10.

${ }^{71}$ See supra note 54, at 11.

${ }^{72}$ See FTC Unfairness Policy Statement, Appended to International Harvester Co., 104 F.T.C. 949, 1076 (1984); see also Beales supra note 43.

${ }^{73}$ As a practical matter, it may be difficult to segregate airfare data from hotel and car data-especially for consumers who purchase bundles of two or more services for one itinerary. Thus, as a practical matter OTAs may adhere to DOT standard for all data. 
enforcement. ${ }^{74}$ Second, while DOT's roots are in the regulation of transportation, the FTC has been the nation's consumer protection agency for a century, having developed substantial expertise in advertising generally and online markets, in particular. Third, the FTC's ex-post enforcement-centered approach is far more flexible than DOT's ex-ante rule-based approach. Finally, the FTC's actions are subject to more stringent internal and external checks, and the FTC is less likely to suffer from regulatory capture than DOT.

\section{A. Scope Economies in Enforcement}

If moving oversight of OTA airfare offerings from one agency to another merely shifted costs from one agency to another, society should be indifferent between sole or dual jurisdiction over OTAs. This, however, is not the case; resting sole jurisdiction with the FTC is likely to be far less expensive and more effective for taxpayers than shared jurisdiction.

First, leaving aside the relative institutional advantages that the FTC enjoys in this regulatory space (discussed below), sole FTC oversight of OTAs is more cost effective for the simple reason that the FTC can police all OTA offerings at once-something DOT could not perform absent Congressional expansion of its jurisdiction. Second, given the FTC's expertise in e-commerce, scope economies in enforcement means that consolidating OTA oversight with the FTC is likely to reduce total government outlays by almost the entire amount that DOT currently devotes to OTA consumer protection enforcement without any degradation of consumer protection..$^{75}$ Indeed, as explained in more detail below, the FTC's expertise and harm-centered approach is likely to improve regulation in this space. Moreover, not only will the FTC's e-commerce experience provide it an advantage in addressing the online sale of air transportation, any experience it

\footnotetext{
${ }^{74}$ See supra Parts I.B and I.C.

${ }^{75}$ This point has equal force with respect to proposed DOT jurisdiction over websites that advertise airfares, but do not sell them. See supra notes 15-19 and accompanying text.
} 
were to gain from policing the online sale of air transportation would complement the remainder of its enforcement portfolio. ${ }^{76}$ For example, the FTC recently addressed the identical issue animating DOT's “full fare advertising" rule. In 2012, the FTC sent letters to 22 hotel operators warning them that failure to disclose resort and other fees associated with hotel bookings on their websites potentially would violate the FTC Act. ${ }^{77}$ Although the FTC's warning letters were targeted at hotel operators rather than OTAs, the similarity of the consumer protection issues and industries involved suggest that that the marginal cost for the FTC to address any perceived problems with OTAs' sale of airline tickets would be close to zero.

\section{B. Institutional Competence}

The DOT was created in 1966 to oversee the nation's interstate transportation systems: rails, roads, and aviation. ${ }^{78}$ Its role with respect to the commercial airline industry was that of traditional utility regulator: through the $\mathrm{CAB}$, it approved pricing, routes, and entry based on a "just and reasonable" standard. ${ }^{79}$ Its consumer protection jurisdiction over airline pricing was an artifact of the political compromises involved in airline deregulation, largely due to the fact that FTC lacked jurisdiction over common carriers, including airlines. ${ }^{80}$ The legislative history makes clear that the

\footnotetext{
${ }^{76}$ It is an economic truism dating back to the $1800 \mathrm{~s}$ that combining complements creates efficiencies. See James C. Cooper et. al., Vertical Antitrust Policy as a Problem of Inference, 23 INT'L J. INDUS. ORG. 639, 643 (2005).

${ }^{77}$ FTC Warns Hotel Operators that Price Quotes that Exclude 'Resort Fees' and Other Mandatory Surcharges May Be Deceptive (Nov. 28, 2012), at 28, http://www.ftc.gov/news-events/press-releases/2012/11/ftc-warns-hoteloperators-price-quotes-exclude-resort-fees-other. (The FTC has conducted a large amount of research on disclosures, generally.)

${ }^{78}$ U.S. DeP'T OF Transp., OfFice of the Historian, The United States DEPARTMENT OF TRANSPORTATION: A BRIEF HISTORY (last accessed March 12, 2015), available at http://ntl.bts.gov/historian/history.html.

${ }^{79}$ See Viscusi et al., supra note 16, at 612-13.

${ }^{80}$ See H.R. Rep. No. 98-793, at 2861-62 (1984). Congress concluded that it would have to pass separate legislation to give the FTC jurisdiction over airlines. It was opposed to this path in large part due to a concern over the FTC's
} 
consumer protection issues concerning Congress did not involve advertising or other issues related to the sale of airline tickets. ${ }^{81}$ Rather, Congress felt that DOT would be in the best position to use the CAB's old consumer protection power to address issues involving airline conduct, such as "overbooking and denied boarding compensation, limitations on liability for lost or damaged baggage, smoking, [and] discrimination against the handicapped." 82 In short, although DOT clearly enjoys substantial expertise in the field of airline safety and industry practice, there is nothing unique about DOT's airline industry expertise that provides it with an advantage in regulating OTA sales of airline tickets. That is, DOT's experience with the airline industry is not likely to enhance its ability to identify practices relating to the sales of tickets that threaten to harm consumers. In economic jargon, because the marginal value of DOT's airline industry expertise to its consumer protection mission is low, the regulatory economies of scope gained by combining consumer protection with other regulatory issues facing airlines are likely quite small. Regulating consumer-facing airline travel displays of OTAs and search engines is light years from the issues that originally led Congress to vest DOT with this consumer protection authority.

On the other hand, the FTC's expertise is not related to one industry, but to consumer protection across all industries; Congress created the FTC to protect consumers from abusive marketplace practices. ${ }^{83}$ Its pedigree as the nation's primary enforcer against fraud and deception in advertising since 1938 leaves it with unsurpassed knowledge among regulatory bodies in identifying marketing practices that are likely to harm consumers. ${ }^{84}$ In the past year alone, the FTC brought 58 cases involving deceptive

cumbersome rulemaking process and the fact that DOT would still have authority to review international charter flight tariffs. See id. at 2862.

${ }^{81} I d$. at 2862.

${ }^{82}$ Id. at 2860 .

${ }^{83}$ Joshua D. Wright, The Antitrust/Consumer Protection Paradox: Two Policies at War with Each Other, 121 YALE L.J. 2216, 2219-20 (2012).

${ }^{84} \mathrm{Id}$. 
advertising, ${ }^{85}$ held three consumer protection workshops, ${ }^{86}$ and issued guidance on a "green" product claim, weight loss claims, and sports equipment concussion protection claims. ${ }^{87}$ Moreover, this year the D.C. Circuit in POM Wonderful, LLC v. FTC, noted the FTC's 'special expertise in determining what sort of substantiation is necessary to assure that advertising is not deceptive." ${ }^{\prime 8}$

${ }^{85}$ See Federal Trade Commission, Legal Resources, http://www.ftc.gov/tipsadvice/business-center/legal-resources?title $=\&$ type $=$ case \& field_consumer protection_topics_tid $=229 \&$ field_industry_tid=All\&field_date_value[min][date] $=$ January $\% 201 \% \overline{2} \mathrm{C} \% 202014 \&$ field_date_value[max][date] $=\overline{\text { March }} \% 201 \% 2 \mathrm{C} \%$ $202015 \&$ sort by $=$ field_date value\&page $=1$ (showing Advertising and Marketing cases reported from January 1, 2014 to March 1, 2015).

${ }^{86}$ Federal Trade Commission, Fraud Affects Every Community (Oct. 29, 2014), http://www.ftc.gov/news-events/events-calendar/2014/10/fraud-affectsevery-community; Federal Trade Commission, Big Data: Tool for Inclusion or Exclusion (Sept. 15, 2014), http://www.ftc.gov/news-events/events-calendar/ 2014/09/big-data-tool-inclusion-or-exclusion; Federal Trade Commission, Care Labeling Rule (March 28, 2014), http://www.ftc.gov/news-events/eventscalendar/2014/03/care-labeling-rule-ftc-roundtable.

${ }^{87}$ See e.g., Press Release, Federal Trade Commission, FTC Staff Warns Plastic Waste Bag Marketers That Their "Oxodegradable" Claims May Be Deceptive (Oct. 21, 2014), available at http://www.ftc.gov/news-events/pressreleases/2014/10/ftc-staff-warns-plastic-waste-bag-marketers-their-oxodegradable; Press Release, Federal Trade Commission, FTC Alerts Major Retailers to Concerns About Concussion Protection Claims for Athletic Mouthguards Made on Websites (Aug. 21, 2014), available at http://www.ftc.gov/news-events/ pressreleases/2014/08/ftc-alerts-major-retailers-concerns-about-concussion-protection;

Press Release, Federal Trade Commission, FTC Has Updated Guidance for Media Outlets on Spotting False Weight-Loss Claims in Advertising (Jan. 7, 2014), available at $\mathrm{http} / / / \mathrm{www} . \mathrm{ftc}$.gov/news-events/press-releases/2014/01/ftchas-updated-guidance-media-outlets-spotting-false-weight-loss.

${ }^{88} \mathrm{POM}$ at 22; see also POM at 18 (noting the FTC's "particular expertise" in determining whether an advertisement sets forth an "efficacy" or "establishment" claim); id. at 15 ("The Commission is often in a better position than are courts to determine when a practice is deceptive within the meaning of the Federal Trade Commission FTC Act, and that admonition is especially true with respect to allegedly deceptive advertising since the finding of a $\S 5$ violation in that this field rests so heavily on inference and pragmatic judgment.") (internal quotations and citations omitted). 
Not only is the FTC the preeminent agency on advertising, it has unique expertise with respect to the Internet economy. As Commissioner Maureen Ohlhausen recently explained, the FTC has consumer protection jurisdiction over the "vast majority of commercial activity on the Internet," and the agency has exercised this jurisdiction to shape norms in online advertising, privacy, and data security. ${ }^{89}$ For example, in the early part of the millennium, the FTC used its Section 5 authority to force search engines to more prominently demark paid search results from organic search results. ${ }^{90}$ Since the early days of e-commerce, it has used its broad Section 5 authority in an attempt to craft a uniform regulatory approach to privacy and data security concerns. In 1998, the FTC brought its first case against a firm for failing to live up to a promise to care for consumers' data. ${ }^{91}$

Since that time, the FTC has brought over 240 cases involving privacy and data security. ${ }^{92}$ This enforcement-along with several influential reports - has crafted current U.S. policy on data security and privacy. ${ }^{93}$ Additionally, the FTC has been at the forefront of addressing consumer protection issues associated with mobile broadband communications. Last year, for example, the FTC filed

${ }^{89}$ The Procrustean Problem With Prescriptive Regulation, Remarks of Maureen K. Ohlhausen, Commissioner, U.S. Federal Trade Commission (2014), http://www.ftc.gov/system/files/documents/public_statements/291361/140318fsf .pdf.

${ }^{90}$ See FTC Consumer Protection Staff Updates Agency's Guidance to Search Engine Industry on the Need to Distinguish Between Advertisements and Search Results (June 25, 2013), http://www.ftc.gov/news-events/press-releases/2013/ 06/ftc-consumer-protection-staff-updates-agencys-guidance-search.

91 See GeoCities http://www.ftc.gov/enforcement/cases-proceedings/9823015/geocities.

${ }^{92}$ The FTC has brought over 130 spam and spyware cases, more than 40 general privacy lawsuits, over 50 data security cases, and over 20 cases related to COPPA. Federal Trade Commission, 2014 Privacy AND Data SECURITy UPDATE 2-7 (2015), available at http://www.ftc.gov/system/files/documents/ reports/privacy-data-security-update-2014/privacydatasecurityupdate_2014.pdf.

${ }^{93}$ See Woodrow Hartzog \& Daniel Solove, The FTC's Common Law of Privacy, 114 Columbia L. REV. 583 (2014). (In light of its expertise, Congress chose the FTC to administer the Children's Online Privacy Protection Act (COPPA).) See 15 U.S.C. $\S \S 6501-6506$. 
consumer protection complaints against Google, Apple, and Amazon for failing to disclose purchase windows for in-app purchases. ${ }^{94}$ The FTC is also involved in litigation over AT\&T's failure to disclose its policy of "throttling" the data of consumers on unlimited data plans. ${ }^{95}$

The FTC also has a superior capability to engage in research that informs consumer protection policy. Congress set up the FTC to become a "norm-creator" in large part through studying markets. ${ }^{96}$ To help the Commission fulfill this role, Congress gave it the power to subpoena industries for data with which to conduct studies. ${ }^{97}$ The FTC has used this power recently to examine privacy issues surrounding data brokers, and currently it is collecting information on patent assertion entities to explore the extent to which their practices give rise to consumer protection concerns. ${ }^{98}$ The FTC also conducts several workshops every year, in which it convenes industry experts and leading academics to gather

\footnotetext{
${ }^{94}$ Complaint, In the Matter of Google, Inc., No. 1223237 (Sep. 4, 2014), https://www.ftc.gov/system/files/documents/cases/140904googleplaycmpt.pdf; Complaint, FTC v. Amazon, Inc., No. 2-14-cv-01038 (July 10, 2014), https://www.ftc.gov/system/files/documents/cases/140710amazoncmpt1.pdf; Complaint, In the Matter of Apple, Inc., No. 1123108 (Jan. 15, 2014), available at https:/www.ftc.gov/sites/default/files/documents/cases/140115applecmpt.pdf.

${ }^{95}$ See FTC Says AT\&T Has Misled Millions of Consumers with 'Unlimited' Data Promises, Federal Trade Commission, (Oct. 28, 2014), http:/www.ftc.gov/news-events/press-releases/2014/10/ftc-says-att-has-misledmillions-consumers-unlimited-data.

${ }^{96}$ See William E. Kovacic \& Marc Winerman, Competition Policy and the Application of Section 5 of the Federal Trade Commission Act, 76 ANTITRUST L.J. 929, 931 (2010) (One of the motivations for creating the FTC was to establish "abody that could conduct investigations and prepare studies as well as bring administrative cases, so that Section 5 litigation would be embedded in a broad understanding of business practices and their implications.").

${ }^{97}$ See 15 U.S.C. $\$ 46$ (c) (2006).

${ }^{98}$ See Data Brokers: A Call for Transparency and Accountability, Federal Trade Commission, https:/www.ftc.gov/system/files/documents/reports/databrokers-call-transparency-accountability-report-federal-trade-commission-may2014/140527databrokerreport.pdf; see also Patent Assertion Entities, (PAE) study, Federal Trade Commission, http:/www.ftc.gov/policy/studies/patentassertion-entities-pae-study.
} 
information about new issues. These workshops often lead to reports recommending policy or guidance for industry.

For example, in 2009 to 2010, the FTC held a series of workshops throughout the country to solicit opinions on privacy and data security issues. This information gathering resulted in a 2012 report that in many ways operates as a de facto FTC policy statement that guides industry practice in this space. ${ }^{99}$ More recently, the FTC released a report on privacy issues surrounding the Internet of Things, based on a workshop of the same name a year ago. ${ }^{100}$ Further, its workshop on "Drip Pricing" - the very issues that animated the pricing component of the EAPP - formed the basis for the group of warning letters sent to hotel operators concerning failure to disclose "resort" or other fees. ${ }^{101}$ To summarize, Congress gave the FTC a capability that DOT lacks: the ability to conduct in-depth studies of marketplace practices to create legal norms.

On the whole, the FTC's expertise easily generalizes to the airline industry, whereas it's unclear that expertise in the airline

\footnotetext{
${ }^{99}$ The lack of empirical evidence and rigid cost-benefit analysis to support the FTC's policy recommendations in the privacy and data security area has drawn some critics. See, e.g., Commissioner Joshua D. Wright, Dissent from Internet of Things Report (Jan. 27, 2015), https://www.ftc.gov/system/files/documents/ public statements/620701/150127iotjdwstmt.pdf; James C. Cooper, Comment on FTC Strategic Plan 2014-2018, (Sept. 30, 2014), http://papers.ssrn.com/sol3/ papers.cfm?abstract_id=2333794.

${ }^{100}$ The Internet of Things: Privacy \& Security in a Connected World, Federal Trade Commission, https://www.ftc.gov/system/files/documents/reports/federaltrade-commission-staff-report-november-2013-workshop-entitled-internetthings-privacy/150127iotrpt.pdf.

${ }^{101}$ FTC Warns Hotel Operators that Price Quotes that Exclude 'Resort Fees' and Other Mandatory Surcharges May Be Deceptive, Federal Trade Commission, (Nov. 28, 2012), http:/www.ftc.gov/news-events/pressreleases/2012/11/ftc-warns-hotel-operators-price-quotes-exclude-resort-fees-other. The FTC has conducted a large amount of research on disclosures generally. See also FTC James M. Lacko and Janis K. Pappalardo, The Effect of Mortgage Broker Compensation Disclosures on Consumers and Competition: $A$ Controlled Experiment, (Feb. 2004), http://www.ftc.gov/sites/default/files/ documents/reports/effect-mortgage-broker-compensation-disclosuresconsumers-and-competition-controlled-experiment/030123mortgagefullrpt.pdf.
} 
industry provides any advantage in addressing consumer protection issues surrounding the online sales of air travel.

That is, although airline industry expertise-which DOT undoubtedly possesses - is valuable in setting safety standards or addressing consumer issues like chronic delays or baggage issues, it provides no advantage in addressing issues like online advertising, privacy, or data security. Accordingly, if the FTC were to replace DOT as the primarily regulator of airline sales on OTAs, any reduction in institutional competence from a loss in airline industry expertise would be more than offset by the enormous gains in consumer protection expertise, particularly expertise on issues surrounding the Internet economy.

\section{Flexibility from Ex-Post, Harm-Based Enforcement}

As a general matter, agencies typically have two tools in their arsenals to enforce their statutory mandate: (1) ex ante rulemaking and (2) ex post case-by-case enforcement. The former avenue typically involves a "notice and comment" procedure, in which the agency collects information, considers various stakeholder viewpoints, and ultimately promulgates a regulation with the force of law that proscribes certain practices. ${ }^{102}$ Regulated entities that engage in these practices are consequently deemed to have violated the relevant statutory provisions. Alternatively, under an ex post enforcement strategy, the agency issues complaints against regulated entities that are alleged to have engaged in conduct that violates the relevant statutory provisions. Depending on the agency, the case proceeds either through federal district courts or administrative adjudication.

As noted above, DOT regulates OTAs primarily through rulemaking that proscribes certain conduct deemed to violate Section 41712. ${ }^{103}$ The FTC - due in large part to the backlash that resulted from its rulemaking frenzy in the 1970s - has abandoned rulemaking and instead relies on a case-by-case enforcement

\footnotetext{
${ }^{102}$ See 5 U.S.C. $\S 553$; Viscusi et al., supra note 16 at 23.

${ }^{103}$ See supra Part II.A.
} 
strategy that is centered on consumer harm. ${ }^{104}$ Although most cases are settled, the series of consent decrees together with the few judicial and Commission decisions have created a quasi-common law in the areas of advertising and privacy. ${ }^{105}$ As noted above, a common law of consumer protection created by FTC enforcement clearly has a deterrent impact on firms' behavior. There is an important distinction, however, in the case of the FTC's harmcentered approach. Whereas a DOT rule proscribes a practice entirely, Section 5 proscribes a practice only if the FTC can show that it is harmful to consumers in each enforcement actiondirectly in unfairness, and indirectly through the materiality requirement in deception. ${ }^{106}$ This distinction has important implications for the relative ability of these agencies to deal with changing conditions.

In theory, ex ante regulation and ex post enforcement can arrive at identical regulatory regimes. Once a case has been decided against one entity, it provides other regulated entities with information about the agency's enforcement posture; a successful challenge to practice $A$ will deter others from engaging in $A$ just as a rule would formally proscribe others from engaging in $A$. In one important aspect, however, ex post enforcement differs from ex ante rulemaking: flexibility. When conditions change rapidly or entities subject to regulation vary, the same conduct may not always violate the statute.

To explain the point more formally, consider a regulator who must choose a level of care, $X$, for regulated entities to take. In the case of consumer protection, $X$ may be the level of substantiation required to make a health claim, the type of disclosure needed in an online display, or the level of data security. The higher the level of substantiation, the greater the level of disclosure, or the more resources devoted to making data secure (the higher the $X$ chosen),

\footnotetext{
${ }^{104}$ The FTC has promulgated rules pursuant to specific statutes (e.g., COPPA; Do Not Call; Safe Guards; and Fairness to Contact Lens Consumers Act).

${ }^{105}$ See Hartzog \& Solove, supra note 93.

${ }^{106}$ For cases that settle, the Commission need only to find "reason to believe" that there has been a violation of the FTC Act and that accepting the settlement is "in the public interest." 15 U.S.C. $\S 45(\mathrm{~b})$.
} 
the less likely consumers are to suffer harm (i.e., being materially misled or having their identity stolen). Such precautions, however, are costly; data security requires software, computer engineers, and information about possible threats; and substantiation requires expensive clinical trials, and extensive disclosures take valuable space from other information and risk increasing consumer information overload. So, the goal of the regulator should be to require an $X$ that minimizes total social costs (TSC) - the summation of expected costs of consumer harm given $X$ and the cost for providing $X$ :

$$
T S C=c X+P(X) * H .
$$

In (1), $c$ is the cost per unit of care, $X$. The term $P(X)$ is the probability of a harmful event occurring (e.g., a data breach or a purchase based on a misrepresentation), and it decreases as more care is taken. Finally, $H$ is the level of harm that occurs when a harmful event occurs. ${ }^{107}$ If $X^{*}$ is the level of care that minimizes TSC given $c, P(X)$, and $H$, it is easy to see that as costs of care, levels of harm, and harm avoidance technologies vary, so will the level of $X^{*}$. Figure 1 shows the optimal level of care as a function of $\theta$, which is a parameter that captures such heterogeneity. This heterogeneity can be thought of as differences in circumstances across regulated entities at a point in time, or as changes in circumstances over time. I assume that higher levels of $\theta$ call for higher levels of $X .^{108}$ The distribution of $\theta$ is shown as $f(\theta)$.

A regulatory regime based on ex post enforcement is far more able than one based on ex ante rules to deal with this type of heterogeneity. Because it is able to consider the facts of each case, in theory the regulator can craft a specific $X^{*}$ for each level of $\theta$. Ex ante rulemaking, on the other hand, will craft a single level of care, which will leave a large proportion of entities taking either too much or too little care depending on their circumstances. For example, suppose that the regulator sets $X^{*}$ based on $\bar{\theta}$, the average

\footnotetext{
${ }^{107}$ This is the standard model for accident liability. See Steven Shavell, Foundations of Economic Analysis of Law 177-206.

${ }^{108}$ For example, $\theta$ could represent sensitivity to harm or lower harm avoidance costs.
} 
of $\theta$, which is distributed normally as shown in Figure $1 .{ }^{109}$ From society's standpoint, entities facing $\theta>\bar{\theta}$ take too little care, and those facing $\theta<\bar{\theta}$ take too much. ${ }^{110}$ Depending on the variance of the distribution, these costs from regulatory mismatch can be substantial. What's more, these costs are magnified to the extent that regulators set $X^{*}$ based on something other than $\bar{\theta}$, which is likely to be the case because realistically regulators will lack sufficient information about the distribution of $\theta$. For example, suppose a regulator over estimates the harm caused by certain conduct and sets $X^{*}$ according to $\tilde{\theta}>\bar{\theta}$. As can be seen in Figure 1 , most of the population suffers from this too stringent standard.

It is true that rules can change to adapt to changing circumstances, but this process is far less nimble than altering ex post enforcement posture. For example, if technological changes render conduct $A$ benign, or new economic learning suggests that $A$ is not harmful, the agency proceeding with an ex post enforcement strategy will either recognize this fact and cease challenging $A$ or it will suffer defeats in court. ${ }^{111}$ In either case, the "rule" created by enforcement changes, and firms will no longer be deterred from conduct $A$. The formal rule that proscribes $A$, on the other hand, will be far more durable. If an agency recognizes $A$ no longer violates the statute, then it must engage in a rulemaking procedure to rescind the rule, a long and politically fraught process. If the agency still clings to the belief that $A$ is harmful, moreover, then repeal of the rule through judicial challenge is almost impossible.

Because the FTC's authority is triggered only with consumer harm-directly in unfairness, and indirectly through the materiality

\footnotetext{
${ }^{109}$ It can be shown that setting $X^{*}$ based on $\bar{\theta}$ is optimal from an ex ante perspective when a regulator must craft only level of care. See, e.g., Steven Shavell, A Model of the Optimal Use of Liability and Safety Regulation, 15 RAND J. ECON. 271 (1984).

${ }^{110}$ This is because $X^{*}(\theta)$ is above $X^{*}(\bar{\theta})$ for $\theta>\bar{\theta}$, and below $X^{*}(\bar{\theta})$ for $\theta<\bar{\theta}$.

111 This scenario occurred with respect to vertical restraints in antitrust. New economic learning suggesting that exclusive territories, exclusive dealing, and resale price maintenance agreements are likely to give rise to efficiencies led the antitrust agencies and courts to adopt a rule of reason approach to these practices rather than a per se prohibition. See Cooper et al., supra note 76.
} 
requirement in deception - it can calibrate its enforcement posture to avoid over- or under-deterrence in a manner the DOT lacks. The Commission's experience using Section 5 to tackle deceptive advertising and privacy issues evidences this capacity. For example, in the realm of advertising, the FTC has calibrated Section 5 to adjust to the burgeoning research on the economics of information in the 1970s and 1980s, and the concomitant shift in Supreme Court views on commercial speech. ${ }^{12}$ The Commission's flexible application of Section 5 to advertising substantiation through the so-called "Pfizer factors" analysis-an approach recently endorsed by the D.C. Circuit ${ }^{113}$ - has been adapted to cover industries ranging from sneakers to drugs. ${ }^{114}$ It mandates a sliding scale of required substantiation depending on factors such as the type of claim made, the type of product, and the consequences of a false claim. ${ }^{115}$ In the area of privacy and data security, the Commission has pursued an approach based on "reasonableness," requiring firms to increase the care taken with the sensitivity of the data collected. ${ }^{116}$ It has used this general framework since 1998 to assure that firms-including Internet

${ }^{112}$ See William Macleod et al., Three Rules and a Constitution: Consumer Protection Finds its Limits in Competition Policy, 72 AnTITRUst L. J. 943, 946 (2005).

${ }^{113}$ See POM Wonderful, LLC v. F.T.C., 777 F.3d 478, 490-92 (D.C. Cir. 2015).

${ }^{114}$ See Pfizer Inc., 81 F.T.C. 23 (1972); Thompson Med Co. v. FTC, 791 F.2d 189 (D.C. Cir. 1986); see also J. Howard Beales, III \& Timothy J. Muris, In Defense of the Pfizer Factors, in THE REgulatory REvOlution AT THE FTC: A Thirty-Year PERspective on COMPETITION AND CONSUMER PROTECTION 83, 91 (James Campbell Cooper ed. 91 (2013). The FTC applied the Pfizer analysis to claims by Sketchers, Sketchers Will Pay $\$ 40$ Million to Settle FTC Charges, FED. TRADE. COMM'N (May 16, 2002), http://www.ftc.gov/newsevents/press-releases/2012/05/skechers-will-pay-40-million-settle-ftc-charges-itdeceived, and Reebok, Reebok to Pay \$25 Million in Consumer Refunds to Settle FTC Charges, FED. TRADE. COMM'N (Sept. 28, 2011), http://www.ftc.gov/newsevents/press-releases/2011/09/reebok-pay-25-million-customer-refunds-settleftc-charges.

115 See Pfizer, Inc., 81 F.T.C. at 3064.

${ }^{116}$ See, e.g., FTC, Protecting CONSUMER PRIVACY IN AN ERA OF RAPID Change (2012). 
economy giants such as Google, Twitter, and Facebook-keep their promises with respect to data collection and uses, and reasonably protect sensitive data they collect. ${ }^{117}$ More recently, the FTC has applied Section 5 concepts to disclosures involving in-app purchases ${ }^{118}$ and mobile broadband throttling ${ }^{119}$ _issues involving industries which would be hard to conceive just 20 years ago, let alone at the FTC's inception in 1914.

In short, the modern FTC has deftly adapted Section 5 to rapidly changing consumer protection issues that have arisen with the exponential growth in technology around the Internet. Had the FTC relied on rulemaking to mandate specific forms of disclosure on mobile platforms, or proscribe certain collection of data, these standards would have rapidly become obsolete and retard economic activity. Rules also impact innovation-when certain conduct is proscribed, companies can be forced to take less efficient paths. Indeed, the type of rigid rule-based regime that DOT seems increasingly to embrace with respect to online entities stands in stark contract to the type of "permissionless" environment-one that allows "experimentation with new technologies and business models ... by default" and takes the position that "problems, if they develop at all, can be addressed later" - that has allowed U.S. technology companies to dominate

${ }^{117}$ The first FTC Internet privacy cases involved deceptive data collection by GeoCities. See GeoCities, FTC File No. 982-3015 (Fed. Trade. Comm'n Feb 12, 1999), http://www.ftc.gov/enforcement/cases-proceedings/982-3015/geocities. Subsequently, the FTC has entered into consent agreements with Google, Google, Docket No. C-4336 (Fed. Trade. Comm'n Nov. 20, 2012), https://www.ftc.gov/enforcement/cases-proceedings/google-inc; Twitter, Twitter, Inc., FTC File No. 092-3093 (Fed. Trade. Comm'n Mar. 11, 2011), https://www.ftc.gov/enforcement/cases-proceedings/092-3093/twitter-inccorporation; and Facebook, Facebook, Inc., FTC File No. 092-3184 (Fed. Trade. Comm'n Aug. 10, 2012), https://www.ftc.gov/enforcement/cases-proceedings/ 092-3184/facebook-inc, for privacy practices alleged to have violated Section 5.

${ }^{118}$ Apple, Inc., FTC File No. 112-3108 (Fed. Trade Comm'n January 23, 2014), https://www.ftc.gov/enforcement/cases-proceedings/112-3108/apple-inc.

${ }^{119}$ Federal Trade Commission v. AT\&T Mobility LLC, No. 3:14-cv-04785 (N.D. Cal. Oct. 28, 2014), https://www.ftc.gov/system/files/documents/cases/ 141028attcmpt.pdf. 
the world market. ${ }^{120}$ This is not to say that FTC enforcement adapts perfectly to all circumstances. Indeed, some of its recent actions in the fields of privacy, data security, and advertising substantiation have drawn criticism from prominent observers for being too unpredictable or too stringent. ${ }^{121}$ Nonetheless, the larger point is that even if some policies are misguided, any costs they impose on the economy will be far less durable than ones imposed by rigid ex ante rulemaking.

Finally, it is important to note that not only is an ex post, harmcentered enforcement approach more flexible than ex ante rulemaking, in most circumstances it will be quicker and cheaper. For example, DOT's EAPP-I began with an Advanced Notice of Proposed Rulemaking in 2007, and was not final until the end of 2009. ${ }^{122}$ The EAPP-II rulemaking took nearly a year from the publication of the Notice of Proposed Rulemaking to the final rule, and likely required substantial staff resources to review comments, and to draft proposed and final rules as well as statements of basis and purpose. ${ }^{123}$ This accounting does not include the staff time and resources that were devoted to the project before the proposals were made public. What is more, once adopted, DOT's rules are

\footnotetext{
${ }^{120}$ ADAm ThIERER, PERMiSSIONLESS INNOVATION vii (2014).

${ }^{121}$ See, e.g., J. Howard Beales, III \& Timothy J. Muris, In Defense of the Pfizer Factors, in THE Regulatory ReVolution AT THE FTC: A THIRTY-YeAR Perspective on COMPETITION AND CONSUMER PROTECTION 83, 93 (James Campbell Cooper ed. 2013) (criticizing some of the FTC's recent advertising substantiation cases); Tom Lenard \& Paul H. Rubin, The FTC Then and Now: Privacy, in The Regulatory Revolution AT THE FTC: A THIRTY-Year PERSPECTIVE ON COMPETITION AND CONSUMER PROTECTION 109, 110 (James Campbell Cooper ed. (2013) (criticizing the FTC's privacy and data security program); James C. Cooper, Identity Theft, Not Big Data, Should be at the Top of the FTC's Priority List, DAILY CALleR (Sept. 24, 2013), http://dailycaller.com/2013/09/24/identity-theft-not-big-data-should-be-at-thetop-of-the-ftcs-priority-list/.

${ }^{122}$ Enhancing Airline Passenger Protections, 72 Fed. Reg. 65,233 (Nov. 20, 2007).

${ }^{123}$ Enhancing Airline Passenger Protections, 76 Fed. Reg. 23,110 (Apr. 25, 2011).
} 
likely to be challenged in court. ${ }^{124}$ Contrast this experience with that of the FTC in adopting Section 5 to data collection, data security, mobile "cramming," throttling, sponsored search disclosures, or in-app purchases. The FTC has been able to leverage enforcement to address each of these novel concerns in the past year. It did not have to wait years for a rulemaking.

\section{External and Internal Constraints}

Internal and external constraints play a large role in shaping the field of possible regulatory outcomes. Because the FTC is subject to more searching judicial review, and enjoys internal procedures that are likely to temper regulatory overreach, its actions are more likely than DOT's to provide consumers with net benefits. Finally, because the FTC is not a sectorial regulator, it is unlikely to suffer regulatory capture.

\section{Judicial Review}

To the extent that DOT continues to exercise its consumer protection jurisdiction through rules rather than adjudication, it will face a lower level of judicial scrutiny than the FTC. ${ }^{125}$ Agency rules promulgated through informal rulemaking - the "notice and comment" procedure that DOT uses to promulgate rules under Section 41712 — can be set aside if they are "arbitrary, capricious, an abuse of discretion, or otherwise not in accordance with law." 126 This standard is highly deferential to the agency's decision: "The scope of review under the 'arbitrary and capricious' standard is narrow and a court is not to substitute its judgment for that of the agency." ${ }^{27}$ For example, in Spirit Airlines v. DOT, which involved a challenge to DOT's "refund rule," the D.C. Circuit explained that under the "arbitrary and capricious standard," "agencies are not

${ }^{124}$ See, e.g., Spirit Airlines, Inc. v. Dep't of Transp. 687 F.3d 403 (D.C. Cir. 2012); Sabre, Inc. v. Dep't of Transp., 429 F.3d 1113 (D.C. Cir. 2005).

${ }^{125}$ See Joseph E. Harrington, John M. Vernon \& W. KipP Viscusi, ECONOMIES OF ANTITRUST AND REGULATION, 23 REGULATION (2005) ("[T]here are very few binding external controls on the development of regulation").

${ }^{126}$ See Administrative Procedures Act, 5 U.S.C. $§ 706$.

${ }^{127}$ Motor Vehicles Mfg. Ass'n v. State Farm Auto Ins. Co., 463 U.S. 29, 30 (1983). 
required to choose the best solution, only a reasonable one." ${ }^{228}$ In instances in which DOT regulates by interpreting a definition in its statute, as long as the term is open to differing definitions, courts must defer to any "reasonable" interpretation made by the administrator of an executive agency. ${ }^{129}$ The DOT receives even more deference when it regulates by modifying its existing rulesas it did when adopting the airfare advertising requirements under EAPP-II. ${ }^{130}$ Courts "give substantial deference to an agency's interpretation of its own regulations," striking it down only if the interpretation is "plainly erroneous or inconsistent with the regulation." 131

In consumer protection adjudication, the FTC can proceed as a plaintiff in federal district court, ${ }^{132}$ or it can file an administrative complaint, in which case the matter will be tried before an FTC administrative law judge ("ALJ"). ${ }^{133}$ When the FTC files a complaint in district court that alleges conduct to be unfair or deceptive under Section 5, it receives no deference; it is treated just as any other plaintiff and must prove the elements of its claim by a preponderance of the evidence. ${ }^{134}$ Under the administrative route, the Commission also must prove its case by a preponderance of the evidence before an ALJ. ${ }^{135}$ For example, in the POM trial, the Commission needed four experts - each subject to crossexamination-to prove that consumers reasonably took away certain unsubstantiated claims from each of POM's ads. ${ }^{136}$ Either party can appeal the ALJ's ruling to the full Commission, and a defendant can appeal an adverse Commission decision to a federal appeals court, and ultimately to the Supreme Court.

\footnotetext{
${ }^{128}$ Spirit, 687 F.3d at 416 (quoting Petal Gas Storage LLP v. FERC, 496 F.3d 695, 703 (2007)).

${ }^{129}$ See Chevron U.S.A., Inc. v. Natural Resources Defense Council, 467 U.S. 837, 844 (1984).

${ }^{130}$ See Spirit, 687 F.3d at 416.

${ }^{131}$ Id. at 410 .

13215 U.S.C. $\S 45(c)$ (2006).

${ }^{133} 15$ U.S.C. $\S 13(\mathrm{~b})$.

${ }^{134}$ See FTC v. Abbott Labs, 852 F. Supp. 526 (D.D.C. 1994).

${ }^{135} 15$ U.S.C. $\$ 45$ (c) (2006).

${ }^{136}$ See FTC v. POM Wonderful, LLC, ALJ decision at 71-84.
} 
When a federal appeals court reviews an FTC decision that an act or practice was deceptive, it will uphold the Commission's finding if it is supported by "substantial evidence." 137 Although this standard is deferential, it allows the court to conduct a more searching review than the "arbitrary and capricious" standard applied to DOT rulemaking. ${ }^{138}$ As one legal scholar explains, the various agency review standards should be thought of as a "grading curve set by Congress," in which "arbitrary and capricious, the narrowest review, is equivalent to a pass/fail," and the substantial evidence standard translates into allowing regulations with " $\mathrm{C}$ " or " $\mathrm{B}$ " grades to pass. ${ }^{139}$ Even less deference is owed the Commission for findings of unfairness. Because this vague term is potentially so capacious, time and again courts have reserved for themselves the last word on how to interpret the meaning of "unfairness." ${ }^{140}$ Indeed, in recognition of this fact, some legal scholars have suggested that the FTC should utilize antitrust rulemaking to proscribe certain conduct as "unfair" so that its findings would receive more deference in courts. ${ }^{141}$

${ }^{137}$ POM Wonderful, LLC v. F.T.C., 777 F.3d 478, 490-92 (D.C. Cir. 2015).

${ }^{138}$ See Paul R. Verkuil, An Outcomes Analysis of Scope of Review Standards, 44 WM. \& MARY L. REV. 679, 687-88 (2002).

${ }^{139} \mathrm{Id}$. at 692688 .

${ }^{140}$ See e.g., FTC v. Boise Cascade Corp., 637 F.2d 573, 581 (9th Cir. 1980) ("The policies calling for deference to the Commission are, of course, in tension with the acknowledged responsibility of the courts to interpret Section 5."); see also Official Airline Guides, Inc. v. F. T. C., 630 F.2d 920, 927 (2d Cir. 1980 (as to who determines what conduct violates Section 5, "The final word is left to the courts"). See generally James C. Cooper, The Perils of Excessive Discretion: The Elusive Meaning of Unfairness in Section 5 of the FTC Act, $34 \mathrm{~J}$. ANTITRUST ENFORCEMENT 87, 93-97 (2015).

${ }^{141}$ See Royce Zeisler, Note: Chevron Deference and the FTC: How and Why the FTC Should Use Chevron To Improve Antitrust Enforcement, 2014 CoLUM. BUS. L. REV. 266, 291-98 (2014) (suggesting that the FTC could promulgate "fine-grained presumptions" for subsequent Section 5 litigation that will receive Chevron deference); see Justin Hurwitz, Chevron and the Limits of Administrative Antitrust, 72 U. PITT. L. REV. 212 (2010). 
As a practical matter, these differing standards of review mean that inefficient rules promulgated by DOT are more durable than similar "rules" adopted by the FTC through litigation. ${ }^{142}$

Further, even if upheld by an appellate court, an FTC decision finding unfairness or deception is far more fragile than an agency rule that survives a legal challenge. Once challenged unsuccessfully, an agency rule cannot be challenged again-the rule's provisions bind everyone subject to it. An FTC decision, even one upheld by an appellate court, binds only the party to the litigation. True, it serves as precedent, and as such may discourage entities from engaging in the conduct condemned as unfair or deceptive. This precedent, however, will apply only in the circuit of the reviewing court. Further, decisions can be challenged and overturned in subsequent litigation. This outcome is more likely the more poorly reasoned or inefficient the decision.

\section{Internal Procedures}

The FTC's internal makeup and procedures also constrain its actions. To challenge conduct in district court or through administrative litigation, a majority of commissioners must find "reason to believe" that the conduct in question violates Section 5 and that challenging the conduct "is in the public interest." 143 This process requires the Commission to find some evidence of consumer harm-directly in unfairness, and indirectly through the materiality element in deception - in every case that it approves.

The comparison with DOT is stark: there is no requirement that the DOT find consumer harm to initiate a rulemaking proceeding. For example, DOT's recent "display bias" rule proposal rests solely on "allegations" that biased displays have been used "to disadvantage certain airlines in the course of hard-fought contract negotiations," and "concern[s]" that ticket agents "could sell bias to certain airline competitors or bias displays toward carriers that

\footnotetext{
${ }^{142}$ For example, the FTC's authority over, and approach to data security are being challenged in two separate proceedings currently. See LabMD, Inc. v. FTC, 776 F.3d 1275 (11th Cir. 2015); F.T.C. v. Wyndham Worldwide Corp., 799 F.3d 236 (3d Cir. 2015).

${ }^{143} 15$ U.S.C. $\S 45(b)$ (2006).
} 
pay higher segment fee[s]." ${ }^{144}$ Further, as discussed above, DOT need only compile minimal evidence - from public comments and even "general experience" - that a practice is generally harmful to approve a final rule without fear of a court overturning it. ${ }^{145}$ Unlike the FTC, moreover, DOT's evidentiary record is never subject to cross-examination. After the rule is in place, DOT does not consider whether there is actual harm, but only whether a defendant has engaged in some proscribed conduct. The importance of this distinction cannot be overstated: the FTC can condemn conduct only with evidence of direct or indirect consumer harm in every case, whereas once a rule is in place, DOT can enjoin conduct without a scintilla of evidence of actual consumer harm.

Another important distinction that is likely to lead the FTC toward a more reasoned approach to enforcement is that it is a collective, rather than a unitary decision maker. Unlike DOT, the FTC can proceed only if a majority of Commissioners vote for a complaint. Of the five Commissioners that comprise the FTC, only three are from the majority party, so as a practical matter minority views are often taken into account in an effort to achieve consensus in enforcement activities. ${ }^{146}$ Further, views within the majority party voting block are not monolithic, so that even enforcement actions approved by a bare majority are often the product of consensus.

A final feature that strengthens FTC's enforcement is that the Commission receives separate recommendations from the Bureau of Consumer Protection ("BCP") and the Bureau of Economics ("BE") for each enforcement action. The BCP recommendation will explain why the conduct at issue violates the relevant

144 See Transparency of Airline Ancillary Fees and Other Consumer Protection Issues, 79 Fed. Reg. 29970-01.

${ }^{145}$ For example, DOT relied in part on comments posted in an online chat room ("Regulation Room") to support its Full Fare advertising rule in EAPP-II. See Spirit Airlines, Inc. v. U.S. Dep't of Transp., 687 F.3d 403, 411 (D.C. Cir. 2012).

${ }^{146}$ The overwhelming majority of Commission actions are approved by a unanimous vote. 
provision of the FTC Act (e.g., deception; unfairness), and in the case of a consent order, why the proposed remedy is sufficient. ${ }^{147}$ The $\mathrm{BE}$ recommendation examines the economic rationale for the case (e.g., what is the magnitude of consumer harm; does the harm outweigh the benefit to consumers or competition), and explains how approving an enforcement action may impact market performance in the future. ${ }^{148}$

\section{Regulatory Capture}

Finally, it is worth noting that the FTC is in far less danger than the DOT of being "captured." Capture is a widely studied phenomenon in which a regulator aligns its interest with the industry it regulates. ${ }^{149}$ Capture is more likely when a regulator faces only one industry, like DOT's aviation consumer protection division. ${ }^{150}$ The FTC, on the other hand, does not have a constituency. Its general enforcement mandate is spread over multiple industries, meaning that there is little repeat play. ${ }^{151}$

\section{Possible Solutions}

Sketched out below are some possible solutions to the problem of concurrent FTC-DOT consumer protection jurisdiction over OTAs. The most major reforms would require congressional action

\footnotetext{
${ }^{147}$ See, e.g., James C. Cooper \& William E. Kovacic, Behavioral Economics and Its Meaning for Antitrust Agency Decision Making, 8 J.L. ECON. PoLICY 779, 797 (2012).

${ }^{148}$ See James C. Cooper \& William E. Kovacic, Behavioral Economics and its Implications for Regulatory Behavior, 41 J. REG. ECON. 41, 53-54 (2012).

${ }^{149}$ JOSEPH E. HARRINGTON, JOHN M. VERNON \& W. KiPP VISCUSI, ECONOMIES OF ANTITRUST AND REGULATION, 379-80 (2005) (Capture theory "states that either the regulation is supplied in response to the industry's demand for regulation .... or the regulatory agency comes to be controlled by the industry over time.").

${ }^{150}$ See id.

${ }^{151}$ See James C. Cooper et al., Theory and Practice of Competition Advocacy at the FTC, 72 ANTITRUST L.J. 1091, 1104 (2005); Remarks of Timothy J. Muris, Panel Discussion, in Cooper ed., supra note 44, at 16 (explaining that unlike the CAB or OSHA, to which "the capture theory clearly fits," the FTC does not have strong interest groups because most businesses "deal only sporadically with the FTC").
} 
and are likely to be the least politically feasible. Some modest reforms, however, could be implemented to ameliorate this situation with minimal (or no) congressional action.

The broadest reform that would eliminate the FTC-DOT redundancy would be simultaneously to repeal Section 41712 and the FTC's common carrier exemption. Not only would this reform allow the FTC to have jurisdiction over OTAs, it additionally would provide the FTC consumer protection authority over all manner of transportation and telecommunications services. ${ }^{152}$ Such a reform would remove an important remaining vestige of the regulatory era by eliminating the DOT's ability to prescribe regulations for the sale of air transportation and instead allowing the market to dictate consumer practices of airlines and ticket agents subject to the appropriate threat of FTC suit.

Of course the political feasibility of this solution is suspect: it is doubtful that an agency or its congressional overseers willingly would give up regulatory authority over an industry as important as air travel. ${ }^{153}$ Indeed, the FTC has been asking for this reform for years to no avail. ${ }^{154} \mathrm{~A}$ narrower version of this reform-repeal of the FTC's common carrier jurisdiction with respect to only airlines - may be more feasible.

It should be noted that this reform was on the table in 1984 when Congress was disbanding the $\mathrm{CAB}$, but rejected largely because of the need for additional legislation, the FTC's cumbersome rulemaking process, and a fear that the FTC would lack the requisite knowledge of the airline industry. ${ }^{155}$ Although Congress still would have to pass legislation, the FTC has gone

\footnotetext{
${ }^{152}$ Such a reform may also be more attractive given the FCC's recent Title II classification of consumer broadband service.

${ }^{153}$ See Marisam, supra note 4, at 184-85.

${ }^{154}$ See, e.g., Prepared Statement of the Federal Trade Commission on Consumer Privacy: Hearing Before S. Comm. on Commerce, Science, and Tech., 110th Cong. (2010) (statement of Jon Leibowitz, Charman of the Federal Trade Commission), See, e.g., http://www.ftc.gov/sites/default/files/documents/ public_statements/prepared-statement-federal-trade-commission-consumerprivacy/100727consumerprivacy.pdf.

${ }^{155}$ See Marisam, supra note 4 and accompanying text.
} 
through a substantial overhaul in the last thirty years, which may allay some Congressional fears; in 1984, the FTC's excesses of the 1970 s were probably fresh in the mind of Congress, but in the years since, the FTC has abandoned rulemaking and has blossomed into a responsible consumer protection enforcer with its harmbased approach. Further, the FTC has proven itself adept at applying its consumer protection authority to all manner of industries.

A second, more cautious approach would be to amend Section 41712 to cover only airline practices not involving advertising or sales. At the same time, Congress could clarify that Section 5 of the FTC Act reaches ticket agents and ticket sales by airlines despite the common carrier exemption. For example, the DOT would be permitted to enforce or promulgate rules that concern things like baggage fees or tarmac delays, and the FTC would become the sole consumer protection enforcer in the sale of airline travel. Although it would still require congressional action, this solution would have the political advantage of asking for less reform and allowing DOT to retain some consumer protection jurisdiction over airlines. This scheme also has the advantage of freeing OTAs from having to deal with two separate regulatory standards. Further, it would vest each agency with authority over conduct that lies in their core competencies: airline practices with DOT, and consumer sales with FTC.

A third, and even more cautious solution, would be merely to remove "ticket agents" from DOT's consumer protection jurisdiction. The FTC already enjoys concurrent jurisdiction over these entities, so there would be no need to amend Section 5. The only legislative fix would be to amend Section 41712. What's more, in theory DOT and FTC could accomplish this reform without legislative action: the agencies could enter into a memorandum of understanding ("MOU") in which DOT promises to forebear from enforcing Section 41712 with respect to ticket agents or to consult with the FTC and give it the right of first refusal with respect to an action against ticket agents. Such an arrangement could be similar to the MOU between FTC and the CFPB with respect to consumer protection involving consumer financial products, which requires the FTC and CFPB to 
coordinate enforcement and policymaking to avoid "duplication of efforts," and "unnecessary burdens on businesses." 156 Of course, this solution would have the downside of creating two separate standards for online sales of air travel, one for the airlines' site and another for OTAs. Nonetheless, it would be preferable to the current state of affairs that subjects OTAs to two separate consumer protection regulators. Further, to ameliorate any potential problems with two regulators for online air travel sales, Congress could require FTC and DOT to harmonize their policies.

\section{CONCLUSION}

Regulatory reform is something that every administration has strived for since the beginning of the regulatory state. Duplicative regulatory authority not only wastes taxpayer money by requiring two agencies to perform the same task, it risks compounding regulatory compliance costs by subjecting covered entities to potentially inconsistent rules. Duplicative FTC and DOT regulation in the sale of airline transportation stands to be especially costly. The current regulatory regime subjects OTAs to heavy-handed regulation from DOT for their sales of airline tickets, and FTC enforcement authority for the remainder of their portfolio. These costs will only go up as privacy and data security become increasingly more important to consumer protection issues and DOT continues to expand the reach of its regulatory requirements. Avoiding this redundancy requires selecting one agency to provide consumer protection oversight of OTA. Given its institutional expertise and the flexibility its harm-based enforcement provides, the FTC is the clear choice.

\footnotetext{
${ }^{156}$ See Federal Trade Commission, Memorandum of Understanding Between the Consumer Financial Protection Bureau and the Federal Trade Commission at 2 (March 12, 2015), https://www.ftc.gov/system/files/documents/ cooperation_agreements/150312ftc-cfpb-mou.pdf.
} 
